\title{
Effect of Exercise Method and Nutritional Status of Ability VO2max on Basketball Players Performance
}

\author{
Arsil*, Muhammad Fakhrur Rozi \\ Sport Education Program \\ Faculty of Sport Science \\ Padang State University \\ Padang, Indonesia \\ dr.arsi11703@gmail.com, rozi1207@gmail.com
}

\begin{abstract}
This study aims to determine the effect of the method of interval training, circuit training methods, and nutritional status of the VO2 max capacity. The study population was men's basketball player SMAN 1 lemur, amounting to 36 people. The sampling technique in this study using a purposive sampling of 20 people. Data nutritional status was measured using anthropometric assessment using the Body Mass Index (BMI), and to measure VO2 max capacity using the bleep test. Analysis of data using a $2 \times 2$ factorial. The results of data analysis found: (1) The ability of $\mathrm{VO} 2$ max with interval training methods (A1 = 44.67) is higher than the circuit training method $(A 2=$ 42.07), (2) There is an interaction between training methods and nutritional status of the capacity of $\mathrm{VO2} \max (\mathrm{Fh}=$ 23.37> $\mathrm{Ft}=4.05)$, (3) In the category of normal nutritional status, ability VO2 max group that trained with the method of interval $(\mathrm{A} 1 \mathrm{~B} 1=48.48)$ is higher than that trained in methods circuit $(\mathrm{A} 2 \mathrm{~B} 1=44.3)$, (4) In the category of nutritional status is not typical, the ability of $\mathrm{VO2}$ max group that trained with the method of interval $(\mathrm{A} 1 B 2=44.67)$ was not significantly different from the group that trained in methods circuit $(A 2 B 2=42.07)$.
\end{abstract}

Keywords-Exercise, Nutritional status, Vo2max, Basketball

\section{INTRODUCTION}

Indonesian nation is one of the many countries in the world that is loyal carry out development in all fields, including the development in the field of sports. Development in the field of sports directed at improving human quality of skilled, knowledgeable, intelligent, personality, sportsmanship, and healthy physically, and spiritually as an effort to improve the quality of Human Resources (HR).

Sport Basketball is one sport that is developing achievement in Indonasia. This development marked the birth of the competition that was held Unity Basketball Indonesia (PERBASI) ie League Basketball Indonesian Armed with the name: the National Basketball League Indonesia (NBLI) is a league basketball supreme professionally managed in Indonesia, followed by the 10 participating clubs from all over Indonesia.

Basketball games played in four quarters and each - each quarter is 10 minutes. During the match berlangusng players are required to move on is continuous during the attack nor the last time. Because the move is continuous guidance for $4 \times 10$ minutes, basketball players need a good level of physical condition with all the elements that play a role in it. One is the physical condition of durability. [1] says "resistance is kemampau body of someone doing physical activity in a long time with not experience significant fatigue.

To improve the physical conditions required endurance exercise more effective and efficient, with the right training methods. This method of training will be visible on load volume, as well as the load intensity exercise results and success will be read on the outcome of the game. [2] says "all the training methods need to include the principal factor in the method which includes the physical, technical, tactical, psychological and contents / training material". Since the method of exercise is a way - a way that is planned systematically oriented goals

Among the many methods of exercise that can be done to improve the physical condition keamampuan, methods circuit training and interval training method is a training method that is often used physical condition coach. Exercises are prepared in accordance with the principle - the principle of the exercise (the principle of overload, increasing the load principle, the principle of sequential exercises) and the component of the exercise (intensity, volume, frequency, and recovery). Therefore, exercises should be arranged in a planned and systematic, repeated - again and in accordance with the objectives, namely the ability of VO2 max. Brooks and Fahey research results in Junusul hairy (2003: 85) says that "an increase in VO2 max by $20 \%$ by applying endurance exercise program for two to three months, then this could increase VO2 max or aerobic endurance"

This research aims to:

1. Differences in the ability of high school basketball players VO2 max N 1 lemur between groups given method of interval training method training circuit as a whole.

2. Interaction training methods and nutritional status of the ability of high school basketball players VO2 max N 1 lemur.

3. Differences in the ability of high school basketball players VO2 max N 1 lemur between groups using the method of interval training method training circuit in the normal nutritional status. 
4. Differences in the ability of high school basketball players VO2 max $\mathrm{N} 1$ lemur between groups by using interval training workout with circuit training method on nutritional status is not normal

\section{RESEARCH METHODOLOGY}

This type of research is this penelititan Experiment pseudo (Quasi Experiment) aims to obtain information that is approximate to the information that can be obtained with experiments that are actually in a state that does not allow for control and/or manipulate all relevant variables, [3].

The variable in this study is the independent variable, namely, the method of interval training (X1) and circuit training method (X2). Moderator variables, namely, nutritional status (X3). The dependent variable, namely, the ability of VO2 max (Y). Ie experimental design used a $2 \times 2$ factorial.

Data collected from the pretest and posttest in statistical analysis using normality test and t-test with measures calculated as follows:

1. Normality test using Liliefors. Normality test aims to determine whether the data obtained normal distribution or not.

2. Homogeneity test.

3. $2 \times 2$ factorial Anova test, followed by Tukey test

\section{RESULTS AND DISCUSSION}

The first hypothesis testing results indicate that, overall, score capabilities VO2 max, the exercise group interval method is higher than in the group of circuit training method. In other words, the research hypothesis proposed significantly verified. From these findings it can be argued that the method of interval training is more effectively used to increase VO2 max capability of the method of circuit training.

Results related to the interaction hypothesis testing, proving that there is iteration between training methods and nutritional status in the group influence on the ability of VO2 max, or in other words that the research hypothesis proposed significantly verified.

In the group of normal nutritional status are trained in methods of interval gain increased ability $\mathrm{VO} 2$ max higher when compared with the group members with the same category of nutritional status and be trained in methods circuit. In the group of normal nutritional status were not trained in the method of interval, little difference when compared with group members with the same category of nutritional status. In other words, in this category at the interval method and the method of circuit does not occur significant difference. This therefore means that there is interaction effect between training methods and nutritional status of the ability of $\mathrm{VO} 2$ max. This means that the method of exercise and nutritional status is the same effect on the ability of VO2 max, or in other words the effect of exercise methods on the ability of VO2 max depending on nutritional status. This is in accordance with the opinion of the Department of Health (2000.33) "Nutritional status is a state body that describe the health status of a person or people in everyday life due to the interaction of the food, the human body and the environment". The normal nutritional status must be obtained from foods that contain nutrients and consumed daily. The function of these nutrients are as a custodian of tissue in the body, replacing damaged cells, regulating metabolism and regulate keseimbanga water, mineral and acid-base balance in body fluids, plays a role in the body's defense mechanism against disease as well as the growth of the body, and as a source of energy or personnel to perform daily activities [4]. This is in accordance with the opinion of the [5] "Nutritional status is a state body that describe the health status of a person or people in everyday life due to the interaction of the food, the human body and the environment". The normal nutritional status must be obtained from foods that contain nutrients and consumed daily. The function of these nutrients are as a custodian of tissue in the body, replacing damaged cells, regulating metabolism and regulate keseimbanga water, mineral and acid-base balance in body fluids, plays a role in the body's defense mechanism against disease as well as the growth of the body, and as a source of energy or personnel to perform daily activities [4]. This is in accordance with [5] "Nutritional status is a state body that describe the health status of a person or people in everyday life due to the interaction of the food, the human body and the environment". The normal nutritional status must be obtained from foods that contain nutrients and consumed daily. The function of these nutrients are as a custodian of tissue in the body, replacing damaged cells, regulating metabolism and regulate keseimbanga water, mineral and acid-base balance in body fluids, plays a role in the body's defense mechanism against disease as well as the growth of the body, and as a source of energy or personnel to perform daily activities [4]. The normal nutritional status must be obtained from foods that contain nutrients and consumed daily. The function of these nutrients are as a custodian of tissue in the body, replacing damaged cells, regulating metabolism and regulate keseimbanga water, mineral and acid-base balance in body fluids, plays a role in the body's defense mechanism against disease as well as the growth of the body, and as a source of energy or personnel to perform daily activities [4]. The normal nutritional status must be obtained from foods that contain nutrients and consumed daily. The function of these nutrients are as a custodian of tissue in the body, replacing damaged cells, regulating metabolism and regulate keseimbanga water, mineral and acid-base balance in body fluids, plays a role in the body's defense mechanism against disease as well as the growth of the body, and as a source of energy or personnel to perform daily activities [4]. 


\section{CONCLUSION}

Based on the findings of the study and discussion of research results can be summarized as follows:

1. Method of interval training greater influence of the training methods circuits in basketball athlete's VO2 max capability SMAN 1 lemur.

2. There is no interaction between training methods and nutritional status at enhancing the ability of basketball athlete's VO2 max SMAN 1 lemur.

3. In normal nutritional status, method of interval exercise greater influence than circuit training method for enhancing the ability of basketball athlete's VO2 max SMAN 1 lemur.

4. On the nutritional status is not normal, not the differences in effect means that the method of interval training with circuit training method at enhancing the ability of basketball athlete's VO2 max SMAN 1 lemur.

\section{REFERENCES}

[1] Arsil. “Pembinaan Kondisi Fisik”. Padang : Sukabina. 2018, pp. 3-4

[2] Bompa, Tudor O. "Power Training For Sport". Canada : Mocaic Press. 1994. pp. 44-45

[3] Engkos Kosasih. "Olahraga Teknik dan Prasarana Latihan". Jakarta: CV Abadi Press. 1985 pp. 75-76

[4] Gusril. Perkembangan Motorik Pada Masa Anak-Anak. Padang: UNP PRESS. 2016. pp. 22-23

[5] Depkes. “Riset Kesehatan Dasar 2005”. Jakarta. 2006. pp. 34-35

[6] Arsil. "Tes Pengukuran dan Evaluasi Olahraga". Padang : Sukabina. 2000. pp. 36-27

[7] E. Berlian. "Metodologi Penelitian Kualitatif dan Kuantitatif". Padang :Sukabina Press. 2016.pp. 33-34

[8] Fox, El, Bower RW. Fose Ml. "Theory Physhydogical Basic of physical Education and Athletics". Philadhelpia: Saunder Collage Publishing. 1994.pp. 65-66.

[9] G. Bramono. "Kadar Hemoglobin dan Volume Oksigen maksimal ( $\left.\mathrm{Vo}_{2} \mathrm{Max}\right)$ Pemain Persiba Bantul Tahun 2009”. Skripsi. Yogyakarta: FIK UNY. 2014.pp. 66-67

[10] Guyton dan Jhon E. Hall. "Buku Ajar Fisiologi Kedokteran. Terjemahan Akademika Pressindo". Jakarta: Penerbit Buku Kedokteran EGC. 1997.pp.30-31

[11] Harsono. "Coaching dan Aspek-aspek Psikologis Dalam Coaching”. Jakarta: P2I.PTK. 1998.pp. 18-19

[12] Irianto, DP. "Pedoman Praktis Berolahraga untuk Kebugaran dan Kesehatan". Yogyakarta: Andi Offset. 2000.pp.44-45

[13] Irianto, DP. "Pedoman Gizi Lengkap Keluarga \& Olahragawan". Yogyakarta: ANDI OFSET. 2017.pp.3-4

[14] U. Jonath. "Praxis Der Leichtathletic". Berlin. 1973.pp.67-68

[15] J. Kuantaraf dan K Liwijaya Kuantaraf. "Olahraga Sumber Kesehatan”. Bandung: Advent Indonesia. 1992.pp.45-46

[16] J. Hairy. "Fisiologi Olahraga". Jakarta: Depdikbud Dirjen DIKKTI Proyek Pembinaan Tenaga Kependidikan. 1989.pp.10-11

[17] Khairuddin. "Penerapan Ilmu Gizi Dalam Aktivitas Olahraga". Padang: Suka Bina Press. 2016.pp.12-13

18] M. Sadjoto. "Pembinaan Kondisi Fisik dalam Olahraga". Jakarta: Depdikbud. 1998.pp.70-71

[19] Nurhasan. “Aktivitas Kebugaran”. Jakarta: Depdiknas. 2005.pp.1112

[20] Rahmawati, Tuti, \& Marfuah, Dewi. "Gambaran Status Gizi Pada Anak Sekolah Dasar The Description Of Nutritional Status Of Children At Primary School”. J.Profesi, Vol. 14, No. 1, September 2016. pp. 72-76. 